\title{
Aktivitas Residu Ekstrak Biji Barringtonia asiatica(L.) Kurz. terhadap larva Crocidolomia pavonana F. (Lepidoptera : Pyralidae)
}

\author{
Danar Dono ${ }^{\left.1^{*}\right)}$ dan Rismanto ${ }^{2)}$ \\ 1) Jurusan Agroteknologi Fakultas Pertanian Universitas Padjadjaran, \\ Kampus Jatinangor, Bandung 40600 \\ 2) Alumnus Jurusan Agroteknologi Fakultas Pertanian Universitas Padjadjaran, \\ Kampus Jatinangor, Bandung 40600 \\ 'Penulis untuk korespondensi: danardono21@yahoo.com
}

\author{
ABSTRACT \\ Residual Activity of Barringtonia asiatica (L.) Kurz. Seed Extract against \\ Crocidolomia pavonana F. (Lepidoptera : Pyralidae)
}

Barringtonia asiatica seed extract could inhibit feed activity of C. Pavonana larva. By using this extract, wettable powder (WP) and liquid (L) insectisides formula has been made. The residual effect of $B$. asiatica seed extract formula in the plants exposed to the sunshine and the rain against $C$. pavonana has never been tested. The purpose of this experiment was to recognize the residual activity of $B$. asiatica seed extract formula on the mortality of $C$. pavonana larva after spraying on the Chinese cabbage. The experimental design was completely randomized block design consisting of seven treatment. The treatments were the formula of $30 \mathrm{WP}$ added by sesame oil, $30 \mathrm{~L}$ added by sesame oil, $30 \mathrm{WP}, 30 \mathrm{~L}$, biological insecticide ( $B$. thuringiensis), synthetic insecticide ( profenofos), and control (aquadest). Chinese cabbage plants grown in the screen house were sprayed by insecticides appropriate to the treatments. The leaves were harvested at $0,1,2,4,6,8,10,12$, and 14 days after spraying and used as the insects feed prior to examine the residual activity in laboratory. Formula of $30 \mathrm{WP}$ and $30 \mathrm{~L}$ added by sesame oil caused higher level mortality compared to $30 \mathrm{WP}$ and $30 \mathrm{~L}$ without sesame oil. Formula of $30 \mathrm{WP}$ and $30 \mathrm{~L}$ added by sesame oil was cease to cause the death of $C$. pavonana larva at residual age of 12 days and 12,2 days. However, the mortality of the insect caused by the residue of $B$. asiatica seed extract formula was lower than those caused by the residue of biological insecticides and synthetic insecticides.

Key words: Barringtonia asiatica, Crocidolomia pavonana, Insecticide, Residual activity

\begin{abstract}
ABSTRAK
Penelitian rumah plastik ini bertujuan untuk mengetahui hubungan antara kepadatan populasi hama kutu daun persik (Myzus persicae Sulz.), tingkat kerusakan daun dan kehilangan hasil cabai merah (Capsicum annuum). Delapan taraf kepadatan populasi $M$. persicae $(0,2,4,8,16,32,64$, dan 128 ekor / tanaman) masing-masing diinfestasikan pada tanaman cabai pada fase pertumbuhan awal dan fase pembungaan awal. Hasil penelitian menunjukkan bahwa populasi $M$. persicae dan tingkat kerusakan daun oleh hama tersebut berhubungan erat dengan kehilangan hasil cabai merah. Pada tanaman yang diinfestasi $M$. persicae saat fase pertumbuhan awal, hubungan antara kepadatan populasi $(X)$ dengan kehilangan hasil $(Y)$ mengikuti persamaan garis regresi $\mathrm{Y}=19,1865+0,3568 \mathrm{X}$ dengan keefektifan menduga sebesar 73,85\% dan koefisien kerusakan sebesar 0,8724 g/ekor. Persamaan garis untuk tanaman yang diinfestasi $M$. persicae saat fase pembungaan awal adalah $Y=19,8504+$
\end{abstract}


0,3181X dengan keefektifan menduga 62,18 \% dan koefisien kerusakan 0,7179 g/ekor. Hubungan antara tingkat kerusakan daun dengan kehilangan hasil pada tanaman cabai yang diinfestasi $M$. persicae saat fase pertumbuhan awal mengikuti persamaan garis regresi $Y=25,93+64,51 X_{1}+0,26 X_{2}-2,27 X_{3}\{(Y=$ kehilangan hasil (\%); $X_{1}=$ tingkat kerusakan daun oleh $M$. persicae (\%); $X_{2}=$ populasi awal $M$. persicae (ekor/tanaman) dan $X_{3}=$ waktu pengamatan (minggu setelah infestasi) dengan keefektifan menduga 78,75 \% dan koefisien kerusakan 1,577 g/\% kerusakan daun. Persamaan garis untuk tanaman cabai yang diinfestasi $M$. persicae saat fase pembungaan awal adalah $Y=25,59+1164,87 X_{1}+0,08 X_{2}-4,60 X_{3}$, dengan keefektifan menduga 79,18 \% dan koefisien kerusakan 3,72 g/\% kerusakan daun.

Kata kunci: Barringtonia asiatica, Crocidolomia pavonana, insektisida, aktivitas, residu

\section{PENDAHULUAN}

Salah satu tumbuhan yang berpotensi sebagai insektisida nabati yaitu Barringtonia asiatica (L.) Kurz (Lecythidales : Lecythidaceae). Semua bagian dari tanaman ini diketahui mengandung saponin yang dapat menghambat aktivitas makan serangga (Kardinan, 2005). Hama yang dapat dikendalikan dengan menggunakan ekstrak biji $B$. asiatica adalah Crocidolomia pavonana F. (Dono \& Sujana, 2007), suatu hama utama yang menyerang tanaman famili Cruciferae (Kalshoven, 1981). Serangan $C$. pavonana dapat menyebabkan kehilangan hasil mencapai $100 \%$ pada tanaman kubis (Uhan, 1993).

Ekstrak metanol biji B. asiatica memperlihatkan aktivitas insektisida yang tinggi dibandingkan dengan ekstrak daun dan kulit batang dengan LC50 sebesar 0,75\% terhadap kematian larva C. pavonana instar 2 sampai instar 4. Respons larva $C$. pavonana mengindikasikan bahwa senyawa yang terkandung dalam ekstrak biji $B$. asiatica mempunyai aktivitas biologi utama sebagai antifidan (Dono \& Sujana, 2007). Selain itu, ekstrak metanol biji $B$. asiatica pada konsentrasi 0,96\% menyebabkan imago C. pavonana tidak dapat meletakkan telur (Wirahadian, 2007).

Dari ekstrak biji $B$. asiatica dapat dihasilkan formula bahan aktif berbentuk Liquid (L) dan Wettable Powder (WP). Kedua jenis formula ini dapat digunakan sebagai komponen dalam formulasi insektisida nabati. Insektisida nabati perlu dibuat dalam bentuk formula untuk mempermudah penyimpanan, pengangkutan, dan pengaplikasiannya di lapangan (Kardinan, 2005). Dalam formulasi ekstrak biji $B$. asiatica ini perlu diketahui ketahanan residu bahan aktif yang terkandung dalam formula ekstrak biji B. Asiatica terutama terhadap faktor abiotik seperti curah hujan dan lama penyinaran di lapangan. Kedua faktor abiotik tersebut memengaruhi degradasi senyawa aktif pestisida (Moniharapon, 2001; Syahputra, 2005), sehingga berpotensi menurunkan efektivitasnya. Informasi mengenai ketahanan ini diperlukan untuk menentukan interval aplikasi pestisida tersebut dan membandingkan efektivitas antar formula maupun dengan insektisida lain seperti insektisida hayati berbasis mikroba maupun insektisida sintesis. Oleh karena itu, perlu dilakukan penelitian mengenai aktivitas residu formulasi ekstrak biji $B$. asiatica setelah diaplikasikan di lapangan terhadap hama tanaman kubis, C. pavonana.

\section{BAHAN DAN METODE}

Metode penelitian yang digunakan adalah metode eksperimen yang dirancang dalam rancangan acak kelompok dengan tujuh perlakuan dan empat ulangan. Perlakuan percobaan terdiri atas empat formula ekstrak biji B. asiatica (formula $30 \mathrm{WP}, 30$ WP ditambah minyak wijen, $30 \mathrm{~L}$, dan $30 \mathrm{~L}$ ditambah minyak wijen), insektisida biologis berbahan aktif $B$. Thuringiensis, insektisida sintetis berbahan aktif profenofos, dan kontrol.

\section{Penyediaan Ekstrak Biji B. asiatica}

Biji B. asiatica asal Jatinangor dipotong kecil-kecil, dikeringanginkan, dan diblender sehingga menjadi serbuk. Serbuk biji ini direndam di dalam metanol, dengan perbandingan serbuk dan metanol 1:10 (b/v) selama 72 jam, selanjutnya disaring menggunakan kertas saring dan dibilas 
sebanyak tiga kali. Hasil penyaringan diuapkan dengan rotary evaporator pada suhu $55-60^{\circ} \mathrm{C}$ dan penghampaan pada tekanan $580-600 \mathrm{mmHg}$ sehingga diperoleh ekstrak kasar pekat.

\section{Formulasi Insektisida Ekstrak Biji $B$. asiatica}

Formula yang dibuat dari ekstrak biji $B$. asiatica berbentuk Liquid (L) dan Wettable Powder (WP). Pembuatan formula $30 \mathrm{~L}$ sebanyak $100 \mathrm{ml}$ dilakukan dengan mencampur $30 \mathrm{~g}$ ekstrak biji $B$. asiatica, 2,5 ml pengemulsi Tween 80, 2,5 ml Agrostick, dan metanol hingga volume $100 \mathrm{ml}$.. Formula $30 \mathrm{~L}$ dengan minyak wijen dibuat dengan dengan menambahkan $3,75 \mathrm{ml}$ minyak wijen ke dalam formula $30 \mathrm{~L}$.

Formula $30 \mathrm{WP}$ dibuat dengan mencampur $30 \mathrm{~g}$ ekstrak biji $B$. asiatica, $2,5 \mathrm{ml}$ pengemulsi Tween 80, 2,5 ml Agrostick, dan kaolin hingga bobot akhir menjadi 100 g. Ke dalam campuran tersebut ditambahkan $500 \mathrm{ml}$ metanol, dikocok hingga merata, kemudian metanolnya diuapkan. Formulasi 30 WP dengan minyak wijen dibuat dengan menambahan $3,75 \mathrm{ml}$ minyak wijen ke dalam formula 30 L. Pembuatan perlakuan kontrol dilakukan dengan mencampur $2,5 \mathrm{ml}$ pengemulsi Tween 80, 2,5 ml Agrostick, dan akuades hingga volume $100 \mathrm{ml}$.

\section{Penyediaan Larva C. Pavonana}

Larva C. pavonana yang digunakan didapatkan dari Jurusan Hama dan Penyakit Tumbuhan, Universitas Padjadjaran. Larva dipelihara dalam kotak plastik berukuran $40 \mathrm{x} 40 \mathrm{x}$ $10 \mathrm{~cm}$ dan diberi pakan daun sawi bebas pestisida hasil penanaman di rumah kaca Jurusan Hama dan Penyakit Tumbuhan. Larva yang hendak berkepompong dipindahkan ke kotak plastik berisi tanah steril. Kepompong dipindahkan ke dalam kurungan plastik-kasa, tempat pemeliharaan imago dan diberi makan larutan madu $10 \%$ yang diserapkan pada segumpal kapas. Daun sawi bebas pestisida diletakkan dalam wadah kurungan sebagai tempat peletakkan telur. Kelompok telur yang terdapat pada daun sawi ditempatkan ke dalam wadah plastik yang dialasi kertas hisap. Telur menetas menjadi larva dan larva yang telah berkembang menjadi instar 2 digunakan sebagai serangga uji.

\section{Pelaksanaan Percobaan}

Pengujian dilakukan dengan metode penyemprotan pada tanaman sawi di polibag (umur 7-8 minggu) yang diletakkan di tempat terbuka tanpa peneduh. Setelah tanaman diberi perlakuan, penyiraman dilakukan langsung ke tanah. Penyemprotan insektisida uji dilakukan menggunakan hand sprayer pada permukaan daun bagian atas dan bawah, dengan volume 15 $\mathrm{ml} /$ tanaman. Konsentrasi formula yang digunakan adalah $0,02 \mathrm{ml} / \mathrm{ml}$ untuk formula $30 \mathrm{~L}$ demgan dan tanpa minyak wijen, $0,02 \mathrm{~g} / \mathrm{ml}$ untuk formulasi WP dengan dan anpa minyak wijen, $2 \mathrm{ml} / \mathrm{l}$ (konsentrasi tertinggi menurut anjuran) untuk insektisida sintetis berbahan aktif profenofos (Curacron 500 EC), dan 2 gr/l.untuk insektisida B. thuringiensis (Dipel WP)

Daun tanaman sawi perlakuan diambil pada $0,1,2,4,6,8,10,12$, dan 14 hari setelah penyemprotan sebagai pakan serangga uji. Daun dipotong dengan ukuran $4 \times 4 \mathrm{~cm}$ kemudian diletakkan dalam wadah plastik (10 × 9 x $4 \mathrm{~cm})$, selanjutnya dimasukkan 10 larva C. pavonana instar 2 ke dalam satu wadah pengujian. Setelah 72 jam, daun perlakuan diganti dengan daun segar tanpa perlakuan hingga larva yang masih hidup mencapai instar 4.

\section{Pengamatan}

Variabel yang diamati adalah mortalitas larva instar 2 hingga instar 4 dan penghambatan terhadap aktivitas makan. Mortalitas larva dihitung dengan menggunakan rumus (Finney, 1971):

$$
\mathrm{P}=\frac{\mathrm{a}}{\mathrm{b}} \times 100 \%
$$

dimana $: \mathrm{P}=$ Mortalitas (\%), $\mathrm{a}=$ Jumlah larva mati (ekor), $\mathrm{b}=$ Jumlah yang diuji (ekor)

Pengamatan penghambatan aktivitas makan dilakukan dengan mengukur luas daun yang dimakan oleh larva menggunakan milimeterblok transparan. Luas daun yang dimakan oleh larva dinyatakan dalam persentase dengan menggunakan rumus:

$$
\mathrm{FI}=\frac{\mathrm{Dc}-\mathrm{Dt}}{\mathrm{DC}} \times 100 \%
$$

dimana : FI = Penghambatan makan, Dc = Rata-rata luas daun kontrol yang, dimakan,

$\mathrm{Dt}=$ Rata-rata luas daun perlakuan yang dimakan. 
Hubungan antara mortalitas dengan umur residu formulasi ekstrak dianalisis dengan analisis regresikorelasi.

\section{HASIL DAN PEMBAHASAN}

\section{Aktivitas Residu Formula Insektisida Ekstrak Biji $B$. asiatica Terhadap Mortalitas Larva C. pavonana}

Mortalitas larva C. pavonana pada semua perlakuan semakin menurun dengan semakin lamanya umur residu insektisida di daun sawi. Pada ekstrak biji $B$. asiatica semakin terlihat jelas. Pada umur residu 6 dan 8 hari, aktivitas setiap formula ekstrak biji $B$. asiatica telah menurun tetapi residu insektisida profenofos dan $B$. thuringiensis masih menyebabkan mortalitas sebesar $100 \%$ terhadap $C$. Pavonana. Pada umur residu 10 hari, mortalitas yang disebabkan residu insektisida profenofos dan $B$. thuringiensis masih tetap tinggi yaitu $60 \%$ dan $77,5 \%$ (Gambar 1) .

Pada Gambar 1 dapat terlihat bahwa aktivitas residu insektisida yang berasal dari ekstrak

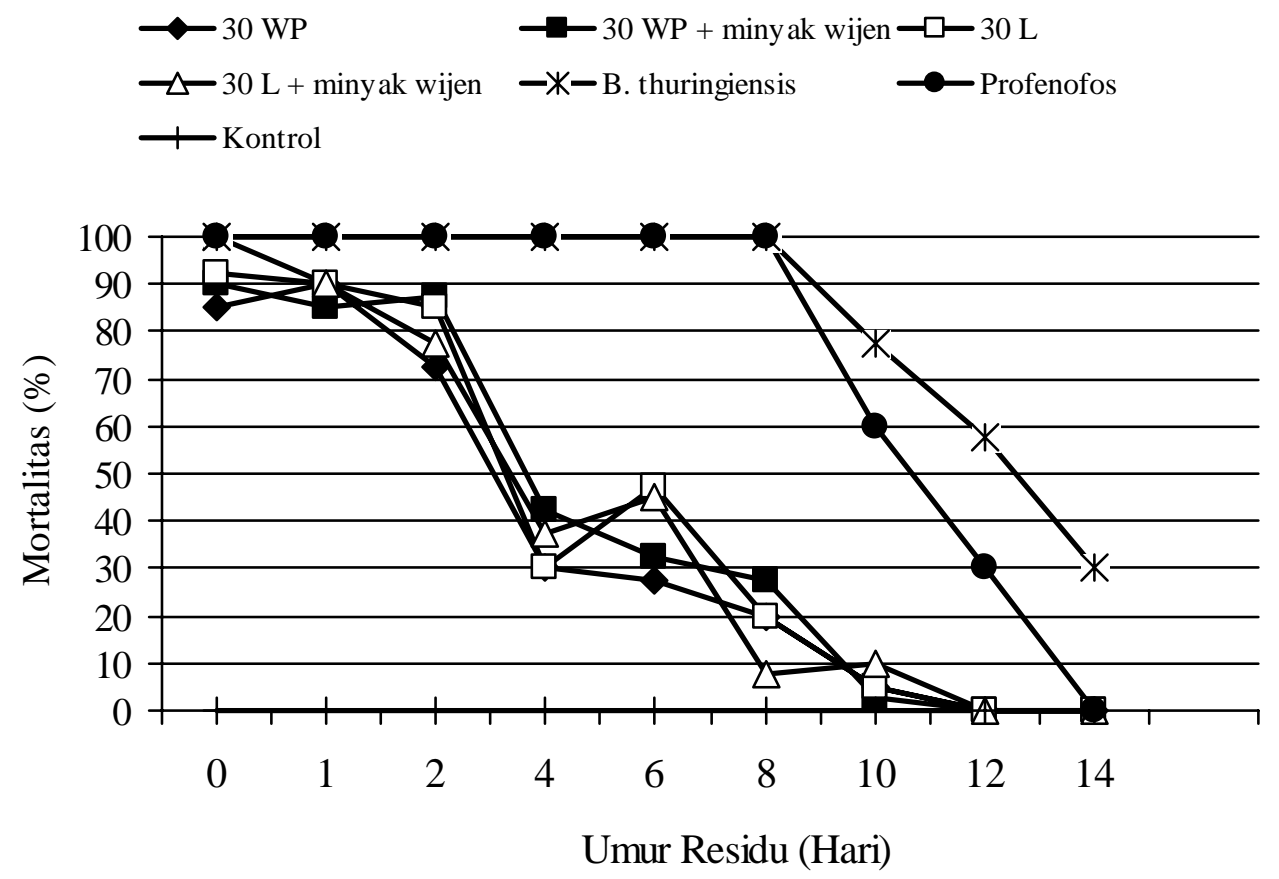

Gambar 1. Grafik mortalitas larva C. pavonana selama waktu perlakuan.

umur residu 0 dan 1 hari, tingkat mortalitas larva pada semua perlakuan ekstrak biji $B$. asiatica tidak berbeda nyata (Gambar 1). Pada umur residu tersebut semua perlakuan ekstrak biji $B$. asiatica menyebabkan mortalitas larva yang tinggi, yaitu lebih dari $80 \%$. Penurunan aktivitas residu ekstrak biji $B$. asiatica mulai terlihat pada residu umur 2 hari. Pada saat itu, aktivitas formulas 30 WP tanpa minyak wijen mulai menurun, sedangkan aktivitas formulai ekstrak biji $B$. asiatica lainnya masih menyebabkan mortalitas yang tinggi, yaitu lebih dari $75 \%$ (Gambar 1).

Pada 4 hari setelah perlakuan, penurunan mortalitas $C$. pavonana pada perlakuan formula biji $B$. asiatica terhadap mortalitas larva $C$. pavonana lebih mudah hilang karena senyawa aktif di dalam ekstrak biji $B$. asiatica lebih mudah terdegradasi dibandingkan dengan insektisida sintetis (profenofos) dan insektisida biologis ( $B$. thuringiensis). Menurut Syahputra (2005) senyawa aktif dapat mengalami degradasi dan perpindahan. Degradasi dapat terjadi oleh aktivitas organisme, reaksi kimia, dan fotodegradasi, sedangkan perpindahan dapat dipengaruhi oleh faktor fisik seperti aliran air dan udara.

Faktor abiotik yang memengaruhi degradasi senyawa aktif yaitu curah hujan dan lamanya penyinaran matahari (Moniharapon, 2001; 
Syahputra, 2005). Curah hujan dan lamanya penyinaran di bulan awal percobaan adalah berturut-turut 13,3 mm/hari dan 3,89 jam/hari sedangkan di bulan akhir perccobaan adalah berturut-turut 2,4 $\mathrm{mm} / \mathrm{hari}$ dan 4,3 jam/hari. Syahputra (2001) melaporkan bahwa residu fraksi aktif kulit batang Dysoxylum acutangulum yang telah terpapar cahaya matahari dan hujan, hanya dapat bertahan pada permukaan tanaman dan masih dapat mematikan larva $C$. pavonana selama tidak lebih dari 5 hari dengan waktu paruh hayati terhadap mortalitas larva $C$. pavonana instar 2- instar 4 adalah 2,5 hari. Ekstrak D. acutangulum yang terpapar cahaya matahari namun terlindung dari pestisida dapat meningkatkan daya racun pestisida tersebut.

Dari persamaan regresi (Tabel 1) dapat diketahui bahwa aktivitas residu formula 30 WP tanpa minyak wijen tidak lagi menyebabkan kematian terhadap larva $C$. pavonana pada umur 12,15 hari, sedangkan formulasi $30 \mathrm{WP}$ ekstrak biji $B$. asiatica yang ditambahkan minyak wijen tidak lagi menyebabkan kematian larva $C$. pavonana pada umur residu 12 hari. Formula $30 \mathrm{~L}$ tanpa minyak wijen tidak lagi menyebabkan kematian pada umur residu 12,40 hari dan aktivitas residu formulasi $30 \mathrm{~L}$ dengan minyak wijen hilang pada umur 12,18 hari. Namun, aktivitas residu formula ekstrak biji $B$.

Tabel 1. Hubungan umur residu dengan mortalitas larva C. pavonana instar 2 sampai dengan instar 4.

\begin{tabular}{|c|c|c|c|}
\hline \multicolumn{4}{|c|}{ Analisis Regresi - Korelasi } \\
\hline Perlakuan & Persamaan Regresi & $\begin{array}{c}\text { Koefisien } \\
\text { korelasi }\end{array}$ & $\begin{array}{c}\text { Koefisien } \\
\text { determinasi }\end{array}$ \\
\hline & & $(\mathrm{r})$ & $\left(\mathrm{R}^{2}\right)$ \\
\hline $30 \mathrm{WP}$ & $Y=66,28-5,38 X$ & -0.95 & 0.90 \\
\hline $30 \mathrm{WP}+$ minyak & $Y=72,82-5,99 X$ & -0.95 & 0.91 \\
\hline $30 \mathrm{~L}$ & $Y=74,06-5,90 X$ & -0.96 & 0.92 \\
\hline 30 L+minyak wijen & $Y=76,67-6,22 X$ & -0.96 & 0.91 \\
\hline B. thuringiensis & $Y=97,10-3,56 X$ & -0.85 & 0.72 \\
\hline Profenofos & $Y=102,20-5,49 X$ & -0.86 & 0.74 \\
\hline
\end{tabular}

Keterangan: $Y=$ Mortalitas, $X=$ Waktu

curah hujan diketahui masih dapat menyebabkan mortalitas larva $C$. pavonana hingga hari ke 14 setelah penyemprotan (Prijono et al., 2006).

Hasil percobaan ini menunjukkan bahwa formula ekstrak biji $B$. asiatica dengan minyak wijen mengakibatkan mortalitas $C$. pavonana lebih tinggi daripada dengan formula tanpa minyak wijen seperti terlihat dari persamaan regresi antara mortalitas larva C. pavonana dengan umur residu (Tabel 1). Penambahan minyak wijen pada formulasi ekstrak biji $B$. asiatica tidak memperpanjang aktivitas residu, tetapi hanya meningkatkan toksisitas terhadap larva C. pavonana. Minyak wijen mengandung bahan sinergis berupa sesamin (Matsumura, 1985; Tarumingkeng, 2001). Bahan sinergis adalah bahan yang tidak beracun namun apabila dicampurkan ke asiatica ini lebih rendah dibandingkan dengan insektisida berbahan aktif $B$. thuringiensis dan insektisida berbahan aktif profenofos. Aktivitas residu insektisida berbahan aktif $B$. thuringiensis tidak lagi menyebabkan kematian larva pada umur residu 27,28 hari sedangkan insektisida berbahan aktif profenofos tidak lagi menyebabkan kematian pada umur residu 18,62 hari.

Koefisien korelasi (r) dari semua formulasi ekstrak biji B. asiatica yang diuji bernilai negatif. Dengan demikian, semakin lama pemaparan maka pengaruh formula ekstrak biji $B$. asiatica terhadap mortalitas larva $C$. pavonana semakin menurun. Berdasarkan koefisien determinasi $\left(\mathrm{R}^{2}\right)$ pada Tabel 1, dapat dijelaskan bahwa penurunan mortalitas larva pada daun sawi yang disemprot formula ektrak biji 
B. asiatica, sekitar $90 \%$ disebabkan oleh lamanya pemaparan.

\section{Aktivitas Residu Formulasi Insektisida Ekstrak Biji B. asiatica Terhadap Aktivitas Makan Larva $C$. pavonana}

Penghambatan makan larva $C$. pavonana oleh insektisida berbahan dasar ekstrak biji $B$. asiatica lebih rendah daripada oleh insektisida sintetik ataupun hayati. Perlakuan formula ekstrak
Selanjutnya, jika larva masih mampu bertahan hidup dan berhasil menjadi pupa kemudian imago, maka imago yang terbentuk biasanya berukuran kecil, cacat, lama hidupnya lebih pendek, dan kemampuan meletakkan telurnya berkurang atau mandul.

Penghambatan makan yang disebabkan aktivitas residu insektisida berbahan aktif profenofos tetap tinggi hingga residu umur 8 hari, dan penurunan yang nyata baru terjadi pada umur residu 10 hari. Hal ini terjadi karena persistensi profenofos

Tabel 2. Penghambatan makan larva C. pavonana oleh residu insektisida

\begin{tabular}{lccccccccc}
\hline & \multicolumn{8}{c}{ Penghambatan makan larva C. pavonana pada umur residu n hari (\%) per } \\
\cline { 2 - 10 } \multicolumn{1}{c}{ Perlakuan } & 0 & 1 & 2 & 4 & 6 & 8 & 10 & 12 & 14 \\
\cline { 2 - 10 } 30 WP & 14,17 & 21,15 & 6,38 & 0,94 & 0,91 & 1,52 & 1,51 & 1,04 & 1,04 \\
30 WP+ minyak & & & & & & & & & \\
wijen & 21,78 & 13,78 & 17,3 & $-0,34$ & 0,21 & 0,97 & 0,99 & 0,81 & 1,42 \\
30 L & 28,5 & 19,83 & 13,40 & 1,43 & 1,25 & 1,28 & 0,38 & 0,15 & 1,51 \\
30 L+ minyak wijen & & & & & & & & & \\
& 88,0 & 22,35 & 8,03 & 2,05 & 2,08 & 0,88 & 1,69 & 0,78 & 1,09 \\
B. thuringiensis & 98,0 & 92,2 & 87,4 & 87,9 & 91,3 & 89,9 & 9,29 & 4,99 & 3,22 \\
Profenofos & 100 & 97,9 & 94,8 & 93,8 & 92,8 & 90,9 & 4,59 & 1,63 & 1,21 \\
Kontrol & 0 & 0 & 0 & 0 & 0 & 0 & 0 & 0 & 0 \\
\hline
\end{tabular}

biji $B$. asiatica dapat menghambat aktivitas makan individu larva $C$. pavonana hanya pada umur residu 0 sampai 2 hari. Efek penghambatan makan larva $C$. pavonana yang disebabkan oleh formula ekstrak biji mulai menurun pada umur residu 4 hari (Tabel 2). Senyawa yang terkandung dalam ekstrak biji $B$. asiatica selain memperlihatkan aktivitas insektisida juga mempunyai aktivitas biologi utama sebagai antifidan (Dono \& Sujana, 2007)

Penghambatan makan larva oleh nsektisida berbahan aktif $B$. thuringiensis tidak menurun dengan nyata sampai umur residu 8 hari. Hal ini disebabkan kristal protein $B$. thuringiensis yang bersifat racun perut masih menyebabkan mortalitas dan juga menghambat aktivitas makan $C$. pavonana yang dapat bertahan hidup. Trizelia (2001) mengemukakan bahwa pada awalnya, residu pestisida menyebabkan aktivitas makan serangga menurun bahkan dapat terhenti. Selain itu, serangga juga menunjukkan penurunan aktivitas gerakan. yang lebih lama sehingga larva $C$. pavonana yang makan pada daun sawi tetap kontak dengan residu insektisida profenofos. Menurut Untung (2006) profenofos merupakan insektisida yang bersifat racun kontak yang dapat masuk ke dalam tubuh selain melalui aktivitas makan juga melalui dinding tubuh.

\section{SIMPULAN}

Formula 30 WP dan $30 \mathrm{~L}$ ekstrak biji $B$. asiatica yang ditambahkan minyak wijen memiliki efek mortalitas terhadap larva $C$. pavonana yang lebih tinggi dibandingkan formulasi $30 \mathrm{WP}$ dan $30 \mathrm{~L}$ tanpa minyak wijen. Formula 30 WP dan $30 \mathrm{~L}$ ekstrak biji $B$. asiatica dengan minyak wijen tidak lagi menyebabkan mortalitas larva pada umur residu 12 hari dan 12,18 hari. Namun, mortalitas yang diakibatkan residu formula ekstrak biji $B$. asiatica lebih rendah daripada mortalitas yang diakibatkan oleh residu insektisida biologis berbahan aktif $B$. 
thuringiensis dan insektisida berbahan aktif profenofos.

\section{UCAPAN TERIMA KASIH}

Penelitian ini merupakan sebagian dari penelitian yang didanai melalui Program Hibah Kompetisi (PHK) A3 pada tahun 2007 Departemen Pendidikan Nasional. Kepada pengelola PHK-A3 Jurusan Hama dan Penyakit Tumbuhan Fakultas Pertanian Universitas Padjadjaran. disampaikan terima kasih.

\section{DAFTAR PUSTAKA}

Dono, D. dan N. Sujana. 2007. Aktivitas insektisida ekstrak Barringtonia asiatica (Lecythidaceae) terhadap larva Crocidolomia pavonana (Lepidoptera: Pyralidae) dan fitotoksisitasnya pada tanaan sawi. Disampaikan pada Simposium Nasional PEI, Sukamandi 10-11 April 2007.

Kalshoven, L. G. E. 1981. The Pests of Crops in Indonesia. Translated and revised by P.A. van der Laan. Ichtiar Baru-van Hoeve. Jakarta.

Kardinan, A. 2005. Pestisida Nabati Ramuan dan Aplikasinya. Penebar Swadaya. Jakarta. Hlm $1-20$.

Matsumura F. 1985. Toxicology of Insecticides, $2^{\text {nd }}$ ed. New York.: Plenum Press.

Moniharapon, DD. 2001. Keefektifan Ekstrak Ranting Aglaia odorata Lour. (Meliaceae) Terhadap Hama Crocidolomia pavonana (F). (Lepidoptera: Pyralidae) Pada Tanaman Brokoli. Tesis Program Pasca Sarjana Institut Pertanian Bogor. 45-51.

Prijono, D., J.I. Sudiar, and Irmayetri. 2006. Insecticidal activity of Indonesian plant extracts against the cabbage head caterpillar, Crocidolomia pavonana (F.)(Lepidoptera: Pyralidae). J. ISSAAS 12: 25-34.

Syahputra, E. 2001. Bioaktivitas Sediaan Dysoxylum acutangulum Miq. (Meliaceae) Terhadap Crocidolomia binotalis Zeller. (Lepidoptera:Pyralidae). Tesis Program Studi Entomologi-Fitopatologi. Program Pasca Sarjana Institut Pertanian Bogor. 102-109.

Syahputra, E. 2005. Bioaktivitas Insektisida Botani Callophylum soutary Byrm I. (Clusiaceae) Sebagai Pengendali Hama Alternative. Disertasi. Sekolah Pasca Sarjana IPB.

Tarumingkeng, R. 2001. Pestisida dan Penggunaanya. Available online at http//:www.rct/bogor/pestisida.html (diakses April, 2007).

Trizelia, 2001. Pemanfaatan Bacillus thuringiensis untuk Pengendalian Crocidolomia binotalis, Zell (Lepidoptera: Pyralidae). Available online at

http://tumoutou.net/3_sem1_072/Trizelia.html (diakses April, 2007).

Uhan, T.S. 1993. Kehilangan hasil panen kubis karena ulat krop kubis (Crocidolomia binotalis Zeller) dan cara pengendaliannya. Holtikultura 3: 22-26.

Untung, K. 2006. Pengantar Pengelolaan Hama Terpadu. Gadjah Mada University Press. Yogyakarta.

Wirahadian, I. 2007. Pengaruh Ekstrak Biji Bitung (Barringtonia asiatica L. (Kurz)) Terhadap Mortalitas dan Oviposisi Crocidolomia pavonana (Lepidoptera:Pyralidae). Skripsi Jurusan Hama dan Penyakit Tumbuhan, Fakultas Pertanian, Universitas Padjadjaran. 